\title{
ПРОБЛЕМЫ ИМПОРТОЗАМЕЩЕНИЯ В ОБРАБАТЫВАЮЩЕЙ ПРОМЫШЛЕННОСТИ РОССИИ
}

\author{
Комкина Т.А.
}

Целью работы является анализ данных по стратегически важным укрупненным направлениям обрабатывающих отраслей производства для выявления рисков, вызываемых зависимостью внутренних товарных рынков от импорта.

DOI: $10.20537 /$ mce2020econ04

Введение. Проводимая в России политика, направленная на развитие сырьевого сектора и сектора услуг, и при этом резкое сокращение обрабатывающих производств привела к технологическому отставанию российской экономики от ведущих стран мира, росту зависимости внутренних товарных рынков от импорта как по отдельным позициям, так и в экономике в целом [1-4].

В связи с этим интерес представляет анализ статистических данных по наиболее стратегически важным укрупненным направлениям обрабатывающих отраслей производства: станкоинструментальное производство; электроника (в том числе микроэлектроники); сельскохозяйственное машиностроение; машиностроение для пищевой и перерабатывающей промышленности; строительно-дорожное машиностроение; производство продукции легкой промышленности.

Анализ структуры обрабатывающей промышленности России. Несмотря на то, что Россия имеет сильную зависимость от поставок сырья (нефти и газа), основными сферами, за счет которых формировался валовый продукт в 2017 г. были операции с недвижимостью - 17.3\%; оптовая и розничная торговля - 15.8 \% (см. табл. 1). Доля обрабатывающей промышленности в структуре ВВП России по отраслям в 2017 г. составила $13.7 \%$ (в 2008 г. - 16.5\%, 1989 г. - 32\%).

Анализ товарной структуры импорта показал, что в 2017 г. основную долю импорта товаров в Россию составили по данным Росстата поставки машин, оборудования и транспортных средств - около 49\% все- 
го импорта; стоимостные объемы поставок увеличились по сравнению с 2016 г. на 27.7\%, см. рис. 1. В стране не принимались меры на государственном уровне по экспортному и импортному регулированию для стимулирования структурных изменений в экономике и защиты внутреннего рынка (импортные и экспортные таможенные пошлины, импортные квоты, валютный контроль, государственное распределение финансовых и материальных ресурсов, противодействие протекционистской политике западных стран и т.д.).

Таблица 1. Структура ВВП России по отраслям 2017 г., \%, расчет по данным [5].

\begin{tabular}{|l|c|}
\hline \multicolumn{1}{|c|}{ Отрасли } & $\mathbf{\%}$ \\
\hline Операции с недвижимостью и другие услуги & 17.3 \\
\hline Оптовая и розничная торговля & 15.8 \\
\hline Обрабатывающие производства & 13.7 \\
\hline Добыча полезных ископаемых & 9.6 \\
\hline Госуправление & 8.2 \\
\hline Транспорт и связь & 7.6 \\
\hline Строительство & 5.2 \\
\hline Финансовая деятельность & 4.9 \\
\hline Сельское хозяйство & 4.4 \\
\hline Здравоохранение & 4.2 \\
\hline Производство электроэнергии, воды, газа & 2.9 \\
\hline Образование & 2.6 \\
\hline Коммунальные услуги & 1.7 \\
\hline Гостиницы и рестораны & 0.9 \\
\hline Домашние хозяйства & 0.7 \\
\hline Рыболовство & 0.3 \\
\hline
\end{tabular}

Основными странами-поставщиками импортных машин и оборудования являлись в 2017 г. Китай - 26\%, Германия - 12\%, США $8 \%$. Рост импорта машин, оборудования и транспортных средств с 2000 г. составил $17.2 \%$.

Снижение конкурентоспособности отечественных предприятий в наиболее стратегически важных укрупненных направлениях обрабатывающих отраслей производства усугубляется прогрессирующим физическим и моральным износом материально-технической базы предприятий (см. рис. 2): показатель степени износа оборудования в среднем по экономике $49 \%$; средний возраст используемых в промышленности машин и оборудования - более 13 лет, в том числе 28\% парка имеет возраст 15-30 лет. 


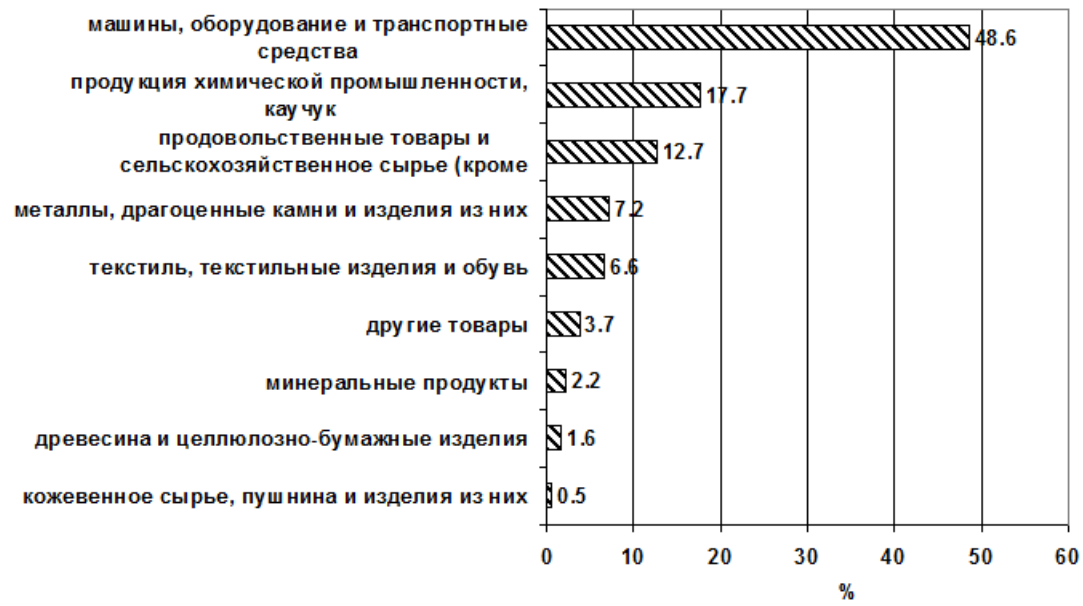

Рис. 1. Товарная структура импорта РФ, 2017 г., \%.

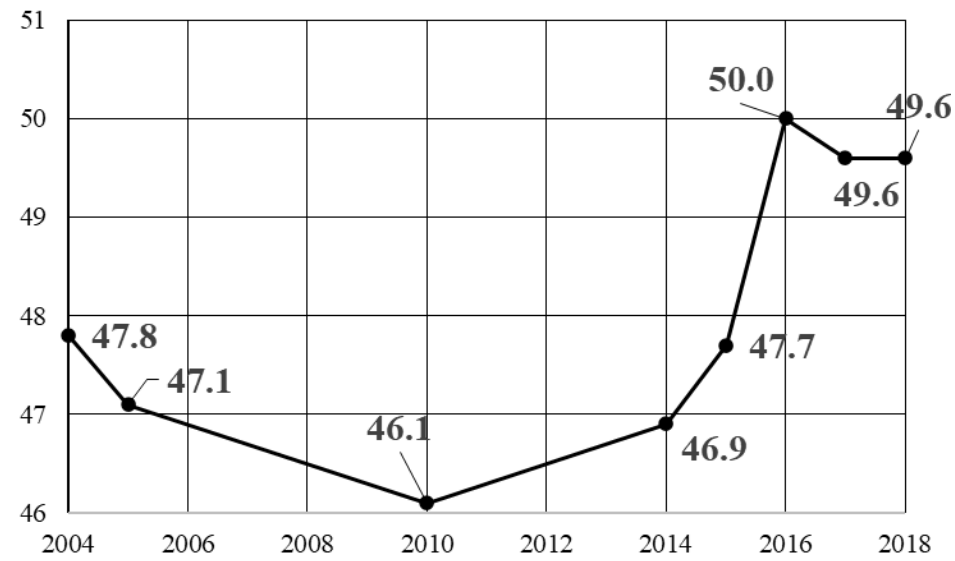

Рис. 2. Динамика изменения степени износа основных фондов в обрабатывающих отраслях в РФ, \%. 
Анализ состояния ряда обрабатывающих производств в РФ.

Станкоинструментальная промышленность. На рынке станкоинструментальной продукции в 2016 г. отечественные производители металлорежущих станков занимали около 10\% внутреннего рынка, кузнечнопрессового оборудования — $5 \%$, а производители инструмента для станков - около 40\% (в стоимостном выражении).

Для минимизации рисков, связанных с зависимостью от импорта, необходима реализация мер по развитию внутреннего производства, как оборудования, так и комплектующих и инструмента. В соответствии со стратегией развития отрасли [6] определены три основные цели: увеличение доли российской продукции на внутреннем рынке до 50\% к 2030 г.; обеспечение роста российского производства со средними темпами не менее $15 \%$ в год; организация конкурентоспособного производства ключевых комплектующих и инструмента.

Электроника. Доля продукции российских предприятий в электронной промышленности составила в 2017 г. 22\% (26\% - включая микроэлектронику). К сегментам российского рынка электроники с высокой долей иностранного оборудования относятся: вычислительная техника - 99.1\%, электроника для энергетики - 93.5\%, автоэлектроника - 91.7\%, потребительская электроника - 91.6\%, связь - 91.5\%, медицинская электроника - 87.5\%, промышленная электроника $82.7 \%$, микроэлектроника - 74\% [7].

Сельскохозяйственное машиностроение. Доля продукции российских предприятий сельскохозяйственной техники на внутреннем рынке в 2016 г. составила 56\% (в количественном выражении), при этом производители тракторов от 100 до 200 л.с. занимали около 6\% внутреннего рынка, тракторов менее 100 л.с. - 36\%, прицепных и навесных сельскохозяйственных машин - 43\%, тракторов свыше 200 л.с. - 60\%, самоходных сельскохозяйственных машин - 72\%. Уровень инвестиций предприятий сельхозмашиностроения в НИОКР по отрасли в 2016 г. составил $0.67 \%$ от выручки (показатель ведущих предприятий отрасли более 4\%) [8]. Средний объем приобретения сельхозтехники за последние 5 лет примерно в 3 раза ниже потенциального объема, а средневзвешенная доля экспорта в отгрузках предприятий составляет 3.9\% [9]. Соответственно производственные мощности предприятий отрасли настоящее время загружены на 40-70 \% (в зависимости от видов техники).

Строительно-дорожное машиностроение. Доля продукции российских предприятий строительно-дорожного машиностроения на 
внутреннем рынке в 2016 г. составила 43\% (в количественном выражении) [10]. В 2017 г. импорт экскаваторов составил 86.5\%, бульдозеров - 71\%, бетономешалок (растворосмесителей) - 47\%, бетононасосов - 44.2\%. Для поддержки отрасли и решения стратегии по импортозамещению Минпромторг уже выделил ряд субсидий, которые должны сделать технику более доступной для потребителей, стимулировать производство машин и их экспортные поставки: компенсация части производственных затрат (части затрат на содержание рабочих мест, части затрат на производство и поддержку гарантийных обязательств, части затрат на использование энергоресурсов), меры поддержки на разработку и освоение производства новых видов продукции, меры поддержки строительно-дорожного машиностроения, направленные на стимулирование внутреннего спроса (субсидии российским организациям для компенсации части затрат на производство и реализацию пилотных партий средств производства потребителям), меры поддержки на разработку и освоение производства новых видов продукции (льготное заемное финансирование - 5\% годовых), меры поддержки продвижения высокотехнологичной продукции на экспорт (субсидирование части затрат на сертификацию продукции на внешних рынках при реализации инвестиционных проектов на транспортировку продукции, на участие в конгрессно-выставочных мероприятиях по продвижению продукции на внешние рынки).

Машиностроение для пищевой и перерабатывающей промышленности. Доля российских предприятий на рынке машиностроения для пищевой и перерабатывающей промышленности составила в 2016 г. 42\% (в стоимостном выражении). В 2015 г. этот показатель составлял 24.7\% (расчет Аналитического центра при Правительстве РФ). К направлениям с высокой долей импорта относятся следующие виды оборудования [11]: для мясной промышленности (включая птицеперерабатывающую) - 94\%; для масложировой промышленности - 90\%, для сахарной промышленности - $81 \%$; фасовочно-упаковочное и весоизмерительное - 79\%; для молочной промышленности - $70 \%$.

На развитие отечественного производства оборудования для пищевой промышленности влияет экономический спад в стране, однако в течение последних 10 лет в России вдвое увеличился импорт оборудования для пищевой и упаковочной промышленности, в первую очередь из Германии [11]. Следует отметить, что положительное влияние на спрос и развитие производства оборудования для пищевой промышлен- 
ности оказывает запрет ввоза продуктов питания из ряда стран, который способствует развитию отечественной пищевой промышленности, что в свою очередь потребует инвестиции в современные технологии производства оборудования для этой отрасли.

Производство обуви. На российском рынке обуви преобладает импортная продукция, доля отечественной кожаной обуви в 2017 г. составляла порядка 50,5\%, текстильной обуви - 48.5\% (в количественном выражении). Основными импортерами являются Китай (80\% в натуральном выражении, 70\% - в стоимостном), Турция (7-9\%), Италия, Германия (по 2-3\%), а также Беларуссия (1.2\%). Особенностью отечественной обувной промышленности является высокая доля производства среднеценовой и низкоценовой обуви, востребованной большей частью населения страны, а также рабочей обуви. Проблемой кожевенного производства на протяжении многих лет остается нехватка сырья, вызванная проблемами в животноводстве в 90-е годы, открытием границ и свободным вывозом кожевенного сырья. В 2000-х гг. по просьбе кожевенных предприятий правительство ввело высокую пошлину на вывоз сырых шкур, что позволило ограничить вывоз кожевенного сырья; как следствие, начался рост кожевенной промышленности. По инициативе Минпромторга в 2014 г. было принято решение о запрете экспорта необработанного полуфабриката. Предприятия кожевенной отрасли выступают за то, чтобы сделать данный запрет постоянным. Основными факторами развития отрасли могут стать недорогое сырье и рост сырьевой базы (ограничение на вывоз кожевенного полуфабриката), падение курса рубля, низкая стоимость рабочей силы в отрасли, программы господдержки.

Выводы. Анализ данных за 2016-2017 гг. по объёму рынка и доли российских компаний на нем по выделенной группе отраслей показал зависимость внутренних товарных рынков от импорта: российские производители станков занимают около 10\% внутреннего рынка, а производители инструмента для станков около $40 \%$; доля продукции российских предприятий строительно-дорожной техники и сельскохозяйственной техники на внутреннем рынке (в количественном выражении) составила $45 \%$ и $43 \%$ соответственно; в электронной промышленности этот показатель составил 26\%. Проведенный анализ свидетельствуют о значительных рисках для безопасности России из-за зависимости от импорта зарубежной продукции и технологий. 
Усугубляет положение физическая изношенность и моральное устаревание материально-технической базы предприятий. Следует также отметить, что существенным препятствием для реализации принятых стратегий развития отраслей промышленности до 2030 г. является недостаток квалифицированных кадров $[13,14]$. Наибольшие проблемы выявлены в отраслях, производящих машины и оборудование - $35 \%$, кожу и изделия из кожи - 32\% [15].

Анализ состояния обрабатывающих производств позволил выявить следующие проблемы: недостаточный темп технологического перевооружения, модернизации и обновления основных фондов, отсутствие целенаправленного спроса со стороны государства как крупнейшего заказчика в ряде инфраструктурных отраслей, недостаточный уровень внедрения инновационных материалов и технологий их производства; низкая конкурентоспособность производителей отдельных видов продукции; потеря научного потенциала, разрушение межотраслевых связей; недостаточный уровень подготовки инженерно-технических специалистов и рабочих кадров.

\section{СПИСОК ЛИТЕРАТУРЫ}

1. Варшавский А.Е. Проблемные инновации: риски для человечества. Экономические, социальные и этические аспекты. - М.: ЛЕНАНД, 2014. 328 с.

2. Варшавский A.E. Макро- и микроэкономические проблемы реиндустриализации России: пути решения // Экономическое возрождение России. 2018. №1. С.23-32.

3. Варшавский $A$. О стратеги научно-технологического развития российской экономики // Общество и экономика. 2017. № 6. С. 5-27.

4. Яркин А. П., Комкина Т. А. Обзор показателей развития промышленности РФ: производство транспортных средств и оборудования // Научнопрактический журнал "Концепции". 2019. Т. 38, № 1. С. 88-90.

5. Российский статистический ежегодник. 1990-2017. URL: https://rosstat.gov.ru/folder/210/document/12994

6. Стратегия развития станкоинструментальной промышленности до 2030 года, Минпромторг России. URL:

http://minpromtorg.gov.ru/common/upload/docs/strategy/project.pdf 
7. Стратегия развития электронной промышленности до 2030 года, Минпромторг России. URL:

http://minpromtorg.gov.ru/docs/\#!strategiya_razvitiya_elektronnoy_promyshlen nosti_rossiyskoy_federacii_na_period_do_2030_goda1233

8. Стратегия развития сельскохозяйственного машиностроения России на период до 2030 года, http://minpromtorg.gov.ru/common/upload/files/strategy_tll_2030.pdf

9. Данные Минпромторга России на основе проведенного анкетирования 53 предприятий Сельхозмашиностроения, http://minpromtorg.gov.ru

10. Корчевой Е.А. Стратегия развития строительно-дорожного машиностроения в РФ до 2030 года. URL: http://xn--80aeabfqidsi0ajui0r.xn-plai/gallery/news/28.pdf

11. Стратегия развития машиностроения для пищевой и перерабатывающей промышленности, Минпромторг России / http://minpromtorg.gov.ru/docs/\#!43220.

12. Обзор пищевой и упаковочной промышленности России, http://chinamachineryfair.ru/russia-foodprocessingandpackaging

13. Варшавский А.Е., Кочеткова Е.В. Анализ показателей численности инженерно-технических специалистов в России // Экономический анализ: теория и практика. 2016. № 9. С. 67-85.

14. Варшавский A.Е., Кочеткова Е.В. Моделирование показателей спроса и предложения инженерно-технических специалистов // Экономический анализ: теория и практика. 2018. Т. 17, № 5 (476). С. 886-905.

15. Деловой климат в промышленности в апреле 2017 г. — М.: НИУ ВШЭ, 2017.

\title{
PROBLEMS OF IMPORT SUBSTITUTION IN RUSSIAN MANUFACTURING INDUSTRIES
}

\author{
Komkina T.A.
}

The aim of the work is to analyze data on strategically important integrated branches of manufacturing industries in order to identify risks caused by the dependence of domestic commodity markets on imports. 